\title{
Law, Robin (ed.). - The English in West Africa
}

\section{Andreas Massing}

\section{(2) OpenEdition}

\section{Journals}

\section{Electronic version}

URL: http://journals.openedition.org/etudesafricaines/14323

DOI: 10.4000/etudesafricaines.14323

ISSN: $1777-5353$

\section{Publisher}

Éditions de l'EHESS

\section{Printed version}

Date of publication: 23 November 2011

Number of pages: 1018-1022

ISBN: 978-2-7132-2299-3

ISSN: 0008-0055

\section{Electronic reference}

Andreas Massing, "Law, Robin (ed.). - The English in West Africa », Cahiers d'études africaines [Online], 204 | 2011, Online since 16 December 2011, connection on 21 September 2020. URL : http:// journals.openedition.org/etudesafricaines/14323; DOI : https://doi.org/10.4000/etudesafricaines. 14323

This text was automatically generated on 21 September 2020.

(c) Cahiers d'Études africaines 


\title{
Law, Robin (ed.). - The English in West Africa
}

\author{
Andreas Massing
}

\section{REFERENCES}

LAW, Robin (ed.). - The English in West Africa: The Local Correspondence of the Royal African Company of England, 1681-1699, Part 3 (1691-1699). Oxford University Press for the British Academy, 2007, 698 p., bibl.

1 This last of three volumes of Royal African Company correspondence contains letters and daybooks from various forts, and minor correspondence from outposts to the Company HQ at Cape Coast (unfortunately, the reply correspondence from Cape Coast is not published).

2 Parts I \& II covering the period 1681-1688 were published in 1997 and 2001, with a gap in 1689/ 1690. The 1437 documents of the 1691-1699 period come from the Bodleian Library's Rawlinson collection which preserves full texts with details on native states and English-African interactions, whereas the National Archives ${ }^{1}$ only keep extracts or summaries. All documents with corresponding index numbers in the Rawlinson collection are listed in appendix "Concordance", followed by an extensive bibliography and four indexes on "Places or Peoples", "Ships", "Person" and "Selected Topics".

The late $17^{\text {th }}$ century was a formative period for Ghanaian states thanks to greater local concentration of power and wealth-with headmen-traders (caboceers) and chiefs. Though the Dutch had introduced firearms since the 1640's, as Kea and Dantzig have shown, and stimulated warfare, but with rising demand for slaves in the Caribbean the English sold more arms. Muskets and powder were in high demand and chiefs would go to lengths to obtain them. From the 1680's onward Denkyira in the North-West and Akwamu further East became main gold suppliers to the coastal Ahanta, Fanti, Efutu and Gan but aimed for direct access to European trade by military means. They broke the monopoly of the Akany traders till 1699 and produced many slaves. 
4 In Europe, the English had deposed James II in the Glorious Revolution of 1688, and called William, Protestant, to reign and marry the heiress Mary. James fled to exile in Paris where Louis XIV laid claim to England and invaded the Protestant Netherlands and parts of the Empire. William organized the anti-French coalition with Holland and the Empire. With its patron's James' disappearance the Royal African Company lost its monopoly in 1698. During the 1690's English and Dutch rivalries which had triggered for Anglo-Dutch wars [1652-1654; 1665-1667; 1672-1674; and 1680-1684] continued. European presence and trade brought major socio-political changes, as interior groups wanted to break the by coastal groups' monopoly of access to the lucrative trade.

By the late $17^{\text {th }}$ century, Ashanti was still a minor power, and could not directly threaten the coastal states. It seems the Akany traders from Ashanti were ousted by Akwamu and Denkyra who became major gold suppliers. The RAC trading posts, sometimes fortified, had to deal with various local partners who themselves traded with interior groups vying for coastal access. The correspondence shows a clear functional differentiation between posts, with a minority serving the export trade, while others served the needs of the forts or ships with food, water or local materials (lime, wood, fibre etc.). It further provides excellent examples of the rivalries not only between various European nations, but also local hosts and interior groups, into which the English were drawn-since those groups competed for the favours of the Europeans. The RAC correspondence also provides cross-checks of some contemporary witnesses such as Barbot and Bosman'2.

Dixcove, so named after "captain" or caboceer Dickie of the town of Incasa, became integrated into the Ahanta chiefdom at Sekondi during the 1680's. The RAC assisted its wars against Adom in the hinterland-frequently provoking Adom requests to remain neutral. The Dutch at Sekondi also tried to get hold of it by payments to local headmen for securing the harbour.

7 Sekondi factory, on Ahanta territory, re-opened in 1683, was involved in a native war from 1691-1694, at which end it was destroyed, and re-opened in 1698. It competed for the gold from Wassa with Dutch forts at Sekondi, Butri and Shama-which prevented it from opening trade with Twifo thus reducing its trade. Adom initially supported a local Ahanta chief, who destroyed the fort; later the Dutch at Butri supported his rival, Yankey, against Adom, which supported the English to rebuilt the fort, while the other Ahanta section remained hostile.

8 Komenda (Eguafo) was open from 1691 till early 1699 and produced a voluminous correspondence. With Dutch encouragement from Elmina and a local Dutch fort, the factory had closed in 1688, and attempts to re-open failed in 1691, but succeeded in 1694. The English alliance with headman John Cabess, under chief Great Takyi, was sabotaged by the Dutch, who allied with Little Takyi, his brother-both claiming the succession. Great Takyi was murdered, when the English suspected him of connivance with the Dutch. Little Takyi now was the sole claimant to the chieftaincy-but still had not secured succession by the end of the 90's. After 1690 the Twifo-Dutch alliesreplace the Akany gold traders, and attack Komenda in 1695. The English tried to open a route through the territory of its ally Adom, but another Dutch attack on Eguafo in 1696 interrupts this. From 1697 onward, however, Twifo, Adom and Denkyira all traded gold at Komenda.

9 Fort Royal, one $\mathrm{km}$ from Cape Coast, at Amanfrom had originally been the headquarters of the Danish Guinea Company, named Fredrixborg. Occupied since 1680 it produced 
correspondence only from 1691 to $1695-$ more in the form of a Daybook than in letters. It was gradually abandoned and found in a state of desolation by Bosman around 1702.

10 Anashan (Biriwa) was an unfortified trade house some $10 \mathrm{~km}$ East of Cape Coast and 5 $\mathrm{km}$ West of Anomabo. Abandoned since 1687, it was evacuated 1691 but reoccupied in 1692, abandoned again 1695 but re-established in 1699. It received a little gold from Akany traders, but was mainly a supplier of corn. It paid tribute to Braffo, head of the Fante state, was involved in the Dutch-English Komenda war (1694-1696) and a projected war against Sabu and Futu (Winneba).

11 Charles Fort, at the local town of Anomabo, belonged to the Fante confederacy, was operated continuously from 1670 until February 1699 thus producing a voluminous correspondence. At neighbouring Kormantin stood wic fort Amsterdam. The Fante had supported the Akany gold traders until a civil dispute resulting in war with Denkyira, caused the deposal of the Braffos and blocked the Akany. Another war (1693-1694) against Cabess Terra (Etsi) in the interior produced many prisoners sold to the English. The garrison's relations with the local community were frequently such that the RAC was forced to remove factors.

12 Egya, one km from Anomabo, was also part of Fante confederation and paid rent and taxes to its Braffo. It was closed in 1691, but re-occupied from 1692 until 1699, and mainly supplied corn to ships but also collected some gold from the Akany and later also from Akim. It participated with Anomabo in the 1693-1694 war against Etsi, which was subdued in 1696. It was also involved in Anomabo's internal dispute over relations with Denkyira-resulting in a split of the confederacy and two Braffos in 1699.

Quashe's Kroom (Amisa) (Amasa) was not the site of a post but part of Fante, and only agent Edward Barter spent several weeks here in 1695 to buy corn from which time date the 7 letters making up this correspondence.

Tantumquerry/Quansa's Kroom, located $27 \mathrm{~km}$ East of Egya and $18 \mathrm{~km}$ East of Amisa, had been abandoned since 1682, but re-claimed in 1693 during French attempts to establish a foothold. A factory was established but abandoned for insufficient trade, as Fante authorities preferred the trade at Kormanin and Anomabo. With the opening of Winneba in 1693 much business was diverted there. Chief Quansa, upon pressure from Acron, visited Cape Coast to request re-opening and another factor was appointed in 1698 mainly for trading corn. Thus, correspondence was produced in 1693 and 1698/9 only. The new Dutch fort (Leydsamheit) at Apam led Acron and Quansa to plan its removal in 1698.

15 Winneba had been established since the 1670's, but was abandoned in 1679, revitalized against French claims in 1682 and 1687. In the 1690's it supplied corn, gold and slaves from its principal partners in Akim (a road North connects Winneba to the Akim capital Oda) and from 1694 on some Akany traders.

Agona's queen Tituba, ruled until her son Auricoo was mature. Akron, a state East of Winneba, had fought against Agona in the 1680's, and Akwamu in the interior which claimed suzerainty over Agona, had captured the Queen in 1689, but by 1693 all were reconciled and asked the English re-open Winneba. Resulting correspondence from 1693-1699 also reports on the 1695-1696 Komenda wars and the 1698 Akani-Denkyira war involving Akron. 
James Fort (Accra) had been established since 1670 and produced a voluminous continuous correspondence. Akwamu conquered Accra in the 80's, held it through the 90's and even occupied the Danish fort Christiansborg. The later Akwamu wars against Adangme, Anlo (Grand Popo) and Whydah (1692-1693), produced great numbers of slaves. Akany traders supplied gold till 1690, but were then replaced by Akim.

Allampo (Adangme) had no factory but only a purchasing agent, who produced few letters.

The Whydah factory's trade at Gléoué had been farmed out to a former interloper. The Dutch maintained a factory at Offra, in neighbouring Allada, which, supported by Whydah, had rebelled against the Dutch in 1690-1691 who destroyed it in 1692, along with a French factory at Whydah. Refugees from the Akwamu conquest of Accra in the 1680 's had settled at Genyi (Little Popo) and helped in the destruction of Offra, but then also attacked Whydah. The letters also mention wars of Little Popo against the Adangme and Grand Popo.

Beside the Factory Correspondence a small volume (about 80 letters) of ship Correspondence was produced classified by coastal and trans-atlantic voyages. For coastal voyages the RAC operated 2 sloops, 1 brigantine, and 2 galleys: the Discovery, a captured interloper, in RAC service since 1688, under captain Richard Bradshaw, later Nicholas Pepperell; the sloop Antilope, under Nicholas Pepperell since 1687; the sloop Alligator, first under Nicholas Pepperell, and Leonard Jeffries from 1689; the brigantine Swallow, under captain R. Bradshaw then Nicholas Peperell; the galley Guinney, operating from 1694, under commander William Piles; finally the Sally Rose, 1696; commander William Piles who went in pursuit of the mutinous Hannibal to Sao Tome in 1697.

21 The Trans-Atlantic ships were all slavers, mostly between Barbados and the Gold \& Slave Coasts, but plied the coast for some time to procure food for their future cargoes. The following were involved: Supply, a captured French ship, serving since 1690 but sold at Barbados in 1693; Fauconburgh, under Francis Buttram coming from Barbados 1691-1692; Abraham Browne in 1695-1696 also bound for Barbados; and John Luke in 1697; Kendal, under James Funnel, 1691-16993; East India Merchant, under Thomas Shirley; afterwards under George Clay; Hannibal under Thomas Phillips bound for Whydah and Barbados, but forced to stop at São Tomé because of an alleged mutiny; John Bonadventure under John Zebbet bound for Little Popo and Barbados; Averilla, under Max Robinson, bound for Barbados in 1695, and captured by the French when returning to England; Adventure, under Samuel Shering, put down a slave revolt at Accra in 1695; Thomas \& Elizabeth, under Benjamin Rawlings, a privateer bound to Barbados; Merchants Goodwill, under Charles Cotterell, in 1698; Prince of Orange, under Josiah Daniel, buying slaves and corn at Tantumquerry in 1698.

An interesting piece on the abortive mutiny on the Hannibal was produced at São Tomé by William Melross, retiring member of the Council of Chief Merchants, on return to England on a Danish ship, which was forced to São Tomé by contrary winds, bad water tanks and fatal illness of its captain.

Some "Foreign Correspondence" from the Dutch fort Elmina dealt with the WIC-RAC dispute over Komenda provoked by expropriation of English goods, or the Brandenburg African Company at Gross Friedrichsburg (Pokesu or Prince's Town West of Dixcove), 
following the death of its Director Jan van Laer. A few witness accounts by Portuguese captains and São Tomé authorities accompany complaints against Elmina.

The bulk of the letters, however, provides vivid details of everyday socio-economic life such as rent and gifts paid, accounts sent, materials requested, received or purchased, workmen's pay, complaints about salary arrears or shortage of funds, bouts of illness, doctors' visits, requests for more personnel-from which we learn about the RAc's own slaves for construction and transport, who were disliked as competition for local labour. Further interesting details on European-African interaction make up the rest such as, for example, "customs" gifts required by headmen on arrival of ships to permit landing or attract traders, oaths on fetishes required as guarantees for "loyalty" in fact of impending threats or attacks, complaints about broken promises, delays or dishonesty with deliveries by local traders. I recommend reading this book with van Dantzig's guide to "Forts and Castles of Ghana" at one's side.

\section{NOTES}

1. Former Public Records Office vol. T70.

$<$ www.nationalarchives.co.uk/ documentsonline>.

2. J. BARBOT, A Description of the North and South Coasts of Guinea, 1681; W. BOSMAN, Nauwkeurige Beschryvingh van de Guinese Gout, Tand en Slavekust, 1703. 